\title{
PENINGKATAN ORGANIZATIONAL CITIZENSHIP BEHAVIOR (OCB) DENGAN CARA ADVERSITY QUOTIENT (AQ) DAN SERVANT LEADERSHIP PADA GURU SMK BERSTATUS PNS SE-KOTA BOGOR
}

\author{
Sri Betty Helena Simamora ${ }^{a)}$, M. Entang ${ }^{b)}$, Yuyun Elizabeth Patras ${ }^{\left.b^{*}\right)}$ \\ a) Guru SMKN 3 Kota Bogor, Jawab Barat \\ ${ }^{b)}$ Universitas Pakuan, Bogor, Indonesia \\ *) e-mail korespondensi: simamorab@yahoo.com
}

Riwayat artikel : diterima: 06 November 2020; direvisi: 16 November 2020; disetujui: 06 Desember 2020

\begin{abstract}
Abstrak. Tujuan dari penelitian ini untuk menjelaskan peningkatan Organizational Citizenship Behavior (OCB) dengan cara Adversity Quotient $(A Q)$ dan Servant Leadership. Penelitian ini merupakan studi empirik menggunakan pendekatan korelasional dan analisis SITOREM pada guru SMK berstatus PNS se-Kota Bogor. Populasi dalam penelitian ini adalah 257 dengan sampel sebanyak 157 orang responden yang diambil dengan teknik Proportional Random Sampling. Pengujian hipotesis yang dilakukan dengan menggunakan analisis statistik parametrik dalam bentuk analisis regresi linier sederhana dan berganda, analisis korelasi sederhana, berganda, dan parsial dengan taraf signifikansi $a=0,01$ dan $a=0,05$. Penelitian ini menghasilkan tiga kesimpulan. Pertama, terdapat hubungan positif yang signifikan antara Adversity Quotient dengan Organizational Citizenship Behavior dengan koefisien korelasi $\mathrm{r}_{\mathrm{y} 1}=0,636$ dan koefisien determinasi $\mathrm{r}_{\mathrm{y} 1}{ }^{2}=0,7172$. Kedua, terdapat hubungan positif yang signifikan antara Servant Leadership dengan Organizational Citizenship Behavior dengan koefisien korelasi $\mathrm{r}_{\mathrm{y} 2}=0,069$ dan koefisien determinasi $\mathrm{r}_{\mathrm{y} 2}{ }^{2}=0,0257$. Ketiga, terdapat hubungan positif yang signifikan antara Adversity Quotient dan Servant Leadership dengan Organizational Citizenship Behavior dengan koefisien korelasi $\mathrm{r}_{\mathrm{y} \cdot 12}=0,4137$ dan koefisien determinasi $\mathrm{r}_{\mathrm{y} \cdot 12}{ }^{2}=0,7218$ Artinya, untuk meningkatkan Organizational Citizenship Behavior guru perlu diiringi dengan penguatan dari Adversity Quotient guru dan Servant Leadership kepala sekolah baik secara bersama-sama atau sendiri-sendiri.
\end{abstract}

Kata Kunci: organizational citizenship behavior; adversity quotient; servant leadership

\section{THE IMPROVEMENT OF ORGANIZATIONAL CITIZENSHIP BEHAVIOR (OCB) BY MEANS OF ADVERSITY QUOTIENT (AQ) AND SERVANT LEADERSHIP OF VOCATIONAL SCHOOL TEACHERS WITH PNS STATUS IN KOTA BOGOR}

\begin{abstract}
The aim of this research was to explain the increase of Organizational Citizenship Behavior (OCB) by means of Adversity Quotient $(A Q)$ and Servant Leadership. The research was an empirical study using a correlational approach and SITOREM analysis. The research was conducted in several vocational school Bogor by taking teachers with civil servants PNS status. The population in this study was 257 with a sample of 157 respondents that determined by using Proportional Random Sampling technique. The Hypothesis was tested by using parametric statistical analysis in the form of simple linear regression and multiple analysis, simple and multiple correlation analysis as well as partial correlation analysis where the significance levels $a=0.01$ and $a=0.05$. The research came up with three conclusions. Firstly, there was a significant positive relationship between Adversity Quotient and Organizational Citizenship Behavior where its correlation coefficient ry $y_{1}=0.636$ and the coefficient of determination ${r_{y l}}^{2}=0.7172$. Secondly, there was a significant positive relationship between Servant Leadership and Organizational Citizenship Behavior where its correlation coefficient $r_{y 2}=0.069$ and coefficient of determination $r_{y 2}{ }^{2}=$ 0.0257. Thirdly, there was a significant positive relationship between Adversity Quotient and Servant Leadership with Organizational Citizenship Behavior where its correlation coefficient $r_{y \cdot 12}=0.4137$ and the coefficient of determination $r_{y \cdot 12}^{2}=$ 0.7218. It means, in order to improve the Organizational Citizenship Behavior, teachers have to strengthening their Adversity Quotient, and schools' principal need to have a better Servant Leadership either in group or individually.
\end{abstract}

Keywords: organizational citizenship behavior; adversity quotient; servant leadership

\section{PENDAHULUAN}

Kualitas sumberdaya manusia pada suatu organisasi dilihat dari seberapa banyak inisiatif yang dilakukan dalam menyelesaikan pekerjaan lainnya diluar dari kewajiban formal. Kemampuan sumberdaya manusia tidak hanya diukur dari kemampuan menyelesaikan tugas-tugas dengan baik. Komponen penting yang perlu diperhatikan adalah perilaku extrarole dan perilaku in-role. Perilaku extra-role merujuk pada usaha untuk melakukan pekerjaan di luar kewajiban formal tanpa mengharapkan suatu imbalan baik berupa materi ataupun non materi, sedangkan perilaku in-role adalah tindakan melakukan pekerjaan sesuai dengan tugas yang ada pada kewajiban formal. Guru adalah sumberdaya dalam suatu organisasi pendidikan bernama sekolah. Organisasi adalah sistem makna bersama dari nilai-nilai bersama dan dimiliki 
bersama oleh organisasi, yang berfungsi untuk menciptakan perbedaan yang jelas antara satu organisasi dengan organisasi lainnya (Suchyadi, 2017). Guru di sekolah berkonsekuensi terhadap kemajuan sekolah. Guru merupakan ujung tombak pendidikan. Pendidikan sangat menentukan kemajuan suatu bangsa. Kemajuan suatu bangsa dilihat dari kualitas pendidikannya. Kualitas pendidikan diperoleh dari kualitas guru. Guru merupakan kunci penting dalam kemajuan suatu bangsa melalui mutu pendidikan yang diberikan. Guru harus mampu beradaptasi karena perubahan seringkali terjadi di lingkungan pendidikan yang dapat berpengaruh terhadap suasana kerja guru.

Guru adalah pendidik profesional dengan tugas utama mendidik, mengajar, membimbing, mengarahkan, melatih, menilai dan mengevaluasi peserta didik dalam tiap jenjang pendidikan. Peran guru saat ini hanya diprioritaskan untuk mengajar saja. Peran guru saat ini hanya dihargai dalam angka kredit maupun kepentingan kepegawaian. Tatap muka 24 sampai dengan 40 jam per minggu. Akibatnya, tugas lain yang juga diemban oleh guru ini kurang mendapat perhatian atau bahkan terkadang tidak terlaksana dengan baik. Guru sibuk memenuhi durasi tatap muka dengan peserta didiknya sehingga terkadang tidak sempat mengamati perkembangan anak didiknya karena peran mengevaluasi tidak berjalan. Adanya Ujian Nasional (UN) semakin menguatkan bahwa tugas utama hanya mengajar saja. Berbagai pendalaman materi disediakan untuk para peserta didik di tingkat akhir untuk memantapkan lagi mata pelajaran yang akan diujikan, namun semuanya hanya pengajaran. Tidak ada bimbingan bagi para peserta didik yang mengalami kesulitan belajar. Ini yang menyebabkan pendidikan sulit untuk membangun karakter bangsa karena guru sebagai kunci keberhasilan pendidikan belum dihargai untuk melakukan keseluruhan tugasnya dengan baik. Kebanyakan guru saat ini melakukan tugas-tugas hanya sekadar menggugurkan kewajiban, terlalu panjangnya durasi tatap muka yang dibebankan menyebabkan peran guru hanya mengajar. Guru bersifat hanya menunggu informasi dan bukan mencari informasi. Beberapa guru juga tidak siap untuk dinilai atau dikritik. Guru akan merasa sulit dalam menerima perubahan, kritik dan masukan dari pihak lain. Seolah-olah guru dianggap tidak kompeten, padahal tujuan kritik dan saran bermaksud untuk meningkatkan performa guru dan memajukan pendidikan nasional. Selain daripada itu, sebagian guru juga tidak serius mengembangkan diri.

\section{Organizational Citizenship Behavior (OCB)}

Menurut Podsakoff dan Mackenzie (1994:351-363) Organizational Citizenship Behavior (OCB) didefinisikan sebagai kebijaksanaan, perilaku ekstra-peran pada bagian dari tenaga penjualan yang telah ditunjukkan untuk mempengaruhi evaluasi kinerja pemimpin/organisasi. Salah satu alasan manajer menghargai Organizational Citizenship Behavior $(O C B)$ adalah karena mereka percaya Organizational Citizenship Behavior (OCB) berkontribusi terhadap kesuksesan organisasi. Sementara menurut Saepudin dan Djati (2019:127) Organizational Citizenship Behavior (OCB) adalah sekumpulan perasaan serta sikap yang dimiliki oleh seseorang terhadap organisasi tempat dia berkerja yang mempengaruhi sejauh mana orang tersebut menyatu dengan organisasi tempat dia berkerja dan mau melakukan hal-hal yang melebihi kewajibanya terhadap organisasi.

Darto (2014:11-12) berpendapat Organizational Citizenship Behavior (OCB) merupakan perilaku yang tergolong bebas tidak sesuai dengan tugas formal yang ditetapkan organisasi, bersifat sukarela, tidak untuk kepentingan diri sendiri, bukan tindakan yang terpaksa dan mengedepankan pihak lain (rekan kerja, lembaga atau organisasi). Berikut ini merupakan dimensi untuk mengukur tingkat Organizational Citizenship Behavior $(O C B)$ seseorang menurut Organ dan Lingl dalam Darto (2014:14-16) (a) Altruism, rasa saling membantu diantara sesama rekan kerja dengan melakukan : (1) Menggantikan rekan kerja yang tidak masuk atau istirahat (2) Membantu orang lain yang pekerjaannya overload, (3) Membantu proses orientasi karyawan baru meskipun tidak diminta, (4) Membantu mengerjakan tugas orang lain pada saat mereka tidak masuk, (5) Meluangkan waktu untuk membantu orang lain berkaitan dengan permasalahan-permasalahan pekerjaan, (6) Menjadi volunteer untuk mengerjakan sesuatu tanpa diminta, (7) Membantu orang lain di luar departeman, (8) Membantu pelanggan dan para tamu jika mereka membutuhkan bantuan. (b)Courtesy, interaksi antar sesama karyawan sehingga sulit untuk saling memberi saran ketika menemukan masalah yang berkaitan dengan pekerjaan pada organisasi dengan melakukan : (1) Menyimpan informasi tentang kejadian-kejadian, maupun perubahan-perubahan dalam organisasi, (2) Mengikuti perubahan-perubahan dan perkembangan- perkembangan dalam organisasi, (3) Membaca dan mengikuti pengumuman organisasi, (4) Membuat pertimbangan dalam menilai apa yang terbaik untuk organisasi. (c) Sportmanship intensitas mengeluh ketika dihadapkan pada situasi yang kurang menguntungkan dengan melakukan : (1) Tidak menemukan kesalahan dalam organisasi, (2) Tidak mengeluh tentang segala sesuatu, (3) Tidak membesar-besarkan permasalahan di luar proporsinya. (d) Conscientiousness, intensitas keterlambatan bekerja setelah istirahat, seringkali karyawan tidak melapor terlebih dahulu ketika tidak masuk kerja dengan melakukan : (1) Tiba lebih awal sehingga siap bekerja pada saat jadwal kerja dimulai, (2) Tepat waktu setiap hari tidak peduli pada musim ataupun lalu lintas dan sebagainya, (3) Berbicara seperlunya dalam percakapan di telepon, (4) Tidak menghabiskan waktu untuk pembicaraan di luar pekerjaan, (5) Datang segera jika dibutuhkan, tidak mengambil kelebihan waktu cuti/libur. (e) Civic virtue, kecenderungan/ketertarikan terhadap kegiatan-kegiatan yang diadakan oleh organisasi dengan melakukan : (1) Memberikan perhatian terhadap fungsi-fungsi yang membantu image organisasi, (2) memberikan perhatian terhadap pertemuanpertemuan yang dianggap penting, (3) Membantu mengatur kebersamaan secara departemental. Berdasarkan beberapa teori Organizational Citizenship Behavior $(O C B)$ yang telah dikemukakan oleh para ahli maka dapat disintesiskan Organizational Citizenship Behavior (OCB) adalah perilaku peran ekstra guru yang dilakukan atas kehendak sendiri tanpa mengharapkan imbalan untuk mencapai tujuan organisasi sekolah. 


\section{Adversity Quotient (AQ)}

Menurut Hema dan Gupta (2015:51) Adversity Quotient ( $A Q$ ) adalah kerangka kerja konseptual yang muncul untuk memahami dan meningkatkan semua aspek keberhasilan; ukuran bagaimana seseorang merespons kesulitan yang dapat dipahami, diubah, dihitung dan ditafsirkan. Oleh karena itu, seperangkat alat yang didasarkan secara ilmiah untuk meningkatkan respons terhadap kesulitan yang menghasilkan efektivitas keseluruhan dalam kehidupan pribadi dan profesional.

Berhubungan dengan sikap intrinsik yang harus dimiliki oleh seseorang, maka Adversity Quotient (AQ) memiliki 4 dimensi yang merupakan bagian dari sikap manusia dalam menghadapi masalah Hema \& Gupta (2015:51) : (a) Pengendalian. Sejauh mana seseorang mampu mempengaruhi dan mengendalikan responnya secara positif terhadap situasi apapun. Pengendalian diri terhadap masalah dalam suatu situasi hampir tidak mungkin diukur. Dimensi kontrol ini merupakan salah satu yang paling penting karena berhubungan langsung dengan pemberdayaan serta mempengaruhi semua dimensi lainnya; (b) Pengakuan. Sejauh mana seseorang mengakui kesalahan yang diperbuat dan tanggung jawab untuk memperbaiki situasi yang terjadi. Dimensi pengakuan sangat berkaitan dengan perasaan bersalah yang dapat membantu sseseorang belajar menjadi lebih baik serta penyesalan sebagai motivator. Rasa bersalah dengan kadar yang tepat dapat menciptakan pembelajaran yang kritis dan dibutuhkan untuk perbaikan terus-menerus; (c) Jangkauan. Sejauh mana seseorang memahami peristiwa baik atau buruk berpotensi meluas ke bidang kehidupan lain; (d) Daya Tahan. Persepsi waktu tentang peristiwa baik atau buruk dan konsekuensinya akan segera berakhir atau bertahan lama.

Verma, Aggarwal dan Bansal (2017:51) berpendapat Adversity Quotient (AQ) dianggap sebagai penentu kinerja dan kesuksesan yang unggul. Adversity Quotient $(A Q)$ yang baik dari seseorang menunjukkan bahwa orang tersebut dapat berjuang melawan semua peluang dan mencapai kesuksesan. Adversity Quotient ( $A Q$ ) membantu seseorang memahami banyak faktor lain seperti harga diri, motivasi, semangat juang, kreativitas, ketulusan, sikap positif, optimisme, stabilitas emosi. Adversity Quotient $(A Q)$ juga dapat membantu seorang guru menilai masalah akademik siswa karena siswa menghadapi banyak tantangan dalam kehidupan dan Adversity Quotient ( $A Q$ ) membantu mengatasi situasi yang menantang ini. Seorang yang mampu menjalani masa-masa sulit pada akhirnya akan dapat mencapai tujuannya. Adversity Quotient $(A Q)$ dapat ditingkatkan dari orang yang memiliki empati, simpati dan jika orang tersebut dapat memahami emosi orang lain. Menurut Tilova (2019:213-214) Adversity berasal dari bahasa Inggris yang berarti kegagalan atau kemalangan. Adversity dapat diartikan sebagai suatu kondisi ketidakbahagiaan, kesulitan, atau ketidakberuntungan. Dalam istilah psikologi Adversity diartikan sebagai tantangan kehidupan.

Berdasarkan beberapa teori Adversity Quotient ( $A Q$ ) menurut para ahli maka dapat disintesiskan Adversity Quotient $(A Q)$ adalah kecakapan individu dalam mengubah kesulitan menjadi peluang dengan cara merencanakan kinerja untuk ketahan malangan dalam hidup sehingga mencapai tujuan yang melampaui harapannya

\section{Servant Leadership}

Menurut Wahyudi (2019:13-14) Servant Leadership adalah bentuk perilaku yang dilakukan oleh seorang pemimpin yang sifatnya melayani karyawan dengan cara berinteraksi langsung dengan karyawan supaya dapat memberi pemahaman dan kenyamanan karyawan dalam bekerja. Rachmawati dan Lantu (2014:388) mengatakan bahwa definisi kepemimpinan oleh pemimpin yang melayani adalah mengutamakan pelayanan, bukan memimpin. Selain itu, para pemimpin yang melayani berusaha mengubah pengikut mereka menjadi lebih sehat, lebih bijaksana, lebih bebas, lebih mandiri, dan lebih mungkin menjadi pelayan. Kepemimpinan pelayan dibangun oleh dua istilah: pemimpin dan pelayan, kedua istilah ini adalah "oxymoron" karena memainkan dua peran berbeda dalam satu waktu, melayani dan memimpin. Mungkin sulit untuk menerima itu sebagai pemimpin, mereka juga melayani. Melayani dan memimpin pada saat yang sama - para pemimpin yang melayani, dan hamba yang memimpin.

Sedangkan menurut Focht dan Ponton (2015:45) Kepemimpinan melayani berawal dari keinginan untuk memberikan layanan kepada individu (bawahan) dan selanjutnya berkembang aspirasi untuk mengarahkan individu kepada tujuan-tujuan tertentu. Dengan kata lain adalah perilaku pemimpin yang didasari dengan keinginan untuk melayani, dan didorong oleh upaya untuk mengarahkan individu lain kepada tujuan-tujuan tertentu. Menurut Liden, Wayne, Zhao, \& Henderson (2008:162) Kepemimpinan melayani didasarkan pada pemahaman bahwa untuk mengeluarkan yang terbaik dari pengikut mereka, para pemimpin mengandalkan komunikasi untuk memahami kemampuan, kebutuhan, keinginan, tujuan, dan potensi individu tersebut. Dengan pengetahuan tentang karakteristik dan minat unik setiap pengikut, para pemimpin kemudian membantu para pengikut dalam mencapai potensi mereka. 3 hal yang mempengaruhi servant leadership antara lain sebagai berikut : (a) Context and Culture. Merupakan kondisi dan budaya yang berada dalam lingkungan sebuah organisasi. (b) Leader Atributes. Merupakan peran karakter serta kemampuan untuk terwujudnya servant leadership yang mencakup pengembangan moral dan kecerdasan emosional. (c) Followers Receptivity. Merupakan kondisi lingkungan yang sesuai dengan harapan karyawan agar terwujudnya servant leadership yang memberikan efek positif terhadap kinerja karyawan.

Adapun dimensi yang mempengaruhi indikator kepemimpinan melayani menurut Focht \& Ponton (2015:50-55) adalah : (a) Value people yaitu menghargai individu/orang lain seperti apa adanya; (b) Humility yaitu rendah hati (humble), menyadari pentingnya individu lain untuk bersama-sama mencapai tujuan organisasi; (c) Listening, yaitu kesediaan mendengarkan,memahami individu lain, serta belajar dari orang lain; (d) Trust yaitu mempercayai orang lain agar dipercaya oleh orang lain; (e) Caring yaitu ramah dan memperhatikan orang lain: kebutuhan dan tujuan (propose) orang 
lain; (f) Iintegrity yaitu jujur dan dipercaya (credible) serta mengembangkan nilai-nilai luhur (kejujuran, kepercayaan, dll) pada anak buahnya; (g) Service yaitu mengutamakan pelayanan kepada orang lain; (h) Empowering yaitu memberdayakan individu lain untuk mengemban tanggungjawab bekerja; (i) Serve other's needs before their own, yaitu melayani kebutuhan orang lain terlebih dahulu sebelum kebutuhannya sendiri; (j) Collaboration kepemimpinan yang melayani adalah tentang mengejar tujuan yang lebih tinggi untuk kebaikan keseluruhan, dan karena kepemimpinan dengan definisi proses kolaboratif (antara pemimpin dan pengikut); (k) Unconditional love yaitu mencakup penerimaan, pengakuan, penghargaan terhadap orang lain, kepercayaan, dan kerentanan.

Berdasarkan beberapa teori para ahli di atas maka dapat disintesiskan Servant Leadership adalah bentuk perilaku seorang kepala sekolah yang memiliki komponen moral dalam membangun strategi dengan tujuan besar bagi organisasi dan selalu mendahulukan kebutuhan umum (pengikut dan organisasi) daripada kepentingan pribadi

\section{METODE PENELITIAN}

Penelitian bertujuan menjelaskan hubungan Adversity Quotient dan Servant Leadership terhadap Organizational Citizenship Behavior $(O C B)$ guru. Penelitian ini dilaksanakan pada guru SMK berstatus PNS se-Kota Bogor dengan menggunakan pendekatan kuantitatif dengan pengujian hipotesis menggunakan analisis SITOREM. Populasi sebanyak 257 guru dengan sampel sebanyak 157 guru. Validitas instrumen diuji menggunakan teknik korelasi Product Moment (Pearson) dan reliabilitas instrumen melalui rumus Alpha Cronbach. Sebelum pengujian hipoteiss dilakukan terlebih dahulu menguji persyaratan analisis data menggunakan uji normalitas galat taksiran dan linieritas regresi. Penelitian ini menggunakan penilaian kuesioner dengan bentuk pernyataan tertutup. Penilaian menggunakan skala Likert, dimulai dari skor 1 , sampai skor 5 ..

\section{HASIL DAN PEMBAHASAN}

\section{Pengujian Persyaratan Analisis}

\section{Uji Normalitas}

Hasil uji normalitas galat baku taksiran $\left(Y-\hat{Y}_{1}\right)$ persamaan regresi variabel $O C B(\mathrm{Y})$ atas $A Q\left(\mathrm{X}_{1}\right)$, diperoleh nilai $\mathrm{L}_{\text {hitung }}$ sebesar 0,0596 sementara $\mathrm{L}_{\text {tabel }}$ untuk $\mathrm{n}=157$ pada taraf signifikansi 0,05 sebesar 0,07071 Galat baku taksiran $\left(Y_{-} Y_{1}\right)$ terdistribusi normal adalah jika $\mathrm{L}_{\text {hitung }}<\mathrm{L}_{\text {tabel }}$. Dengan demikian, galat baku taksiran $\left(Y_{-} Y_{1}\right)$ persamaan regresi variabel $O C B(\mathrm{Y})$ atas $A Q\left(\mathrm{X}_{1}\right)$ berdistribusi 0,0596 atau data sampel berasal dari distribusi normal, karena $\left(\mathrm{L}_{\mathrm{hitung}}=0,0596\right)<\left(\mathrm{L}_{\text {tabel }}=0,07071\right)$. Hasil uji normalitas galat baku taksiran $\left(Y_{-} Y_{2}\right)$ persamaan regresi variabel $O C B$ atas $S L$, diperoleh nilai $\mathrm{L}_{\text {hitung }}$ sebesar 0,0596 sementara $\mathrm{L}_{\text {tabel }}$ untuk $\mathrm{n}=157$ pada taraf signifikansi 0,05 sebesar 0,07071 Galat baku taksiran $\left(Y_{-} Y_{2}\right)$ terdistribusi normal adalah jika $\mathrm{L}_{\text {hitung }}<\mathrm{L}_{\text {tabel }}$. Dengan demikian, galat baku taksiran $\left(Y_{-} Y_{2}\right)$ persamaan regresi variabel $O C B(\mathrm{Y})$ atas $S L$ berdistribusi 0,0596 atau data sampel berasal dari distribusi normal, karena $\left(\mathrm{L}_{\text {hitung }}=0,0596\right)<\left(\mathrm{L}_{\text {tabel }}=0,07071\right)$.

\section{Uji Homogenitas}

Berdasarkan hasil perhitungan, diperoleh nilai $\chi_{\text {hitung }}^{2}$ sebesar 20,8941, sedangkan $\chi_{\text {tabel }}^{2}$ pada taraf signifikansi 0,05

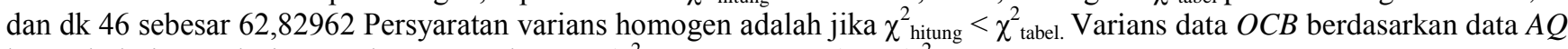
berasal dari populasi yang homogen, karena $\left(\chi_{\text {hitung }}^{2}=20,8941\right)<\left(\chi_{\text {tabel }}^{2}=62,82962\right)$. Berdasarkan hasil perhitungan, diperoleh nilai $\chi_{\text {hitung }}^{2}$ sebesar 62,3476, sedangkan $\chi_{\text {tabel }}^{2}$ pada taraf signifikansi 0,05 dan dk 55 sebesar 72,15322. Persyaratan varians homogen adalah jika $\chi_{\text {hitung }}^{2}<\chi_{\text {tabel. }}^{2}$ Varians data $O C B$ berdasarkan data $S L$ berasal dari populasi yang homogen, karena $\left(\chi_{\text {hitung }}^{2}=62,3476\right)<\left(\chi_{\text {tabel }}^{2}=72,15322\right)$

\section{Pengujian Hipotesis}

\section{Hubungan Antara $A Q$ dengan $O C B$}

Berdasarkan hasil analisis regresi sederhana, diperoleh konstanta regresi atau a $=132,2924$ dan koefisien regresi atau $\mathrm{b}=2,0879$. Dengan demikian, model hubungan antara $A Q$ dengan $O C B$ dapat dinyatakan dalam bentuk persamaan regresi linier $\hat{Y}=132,2924+2,0879 X_{1}$. Berdasarkan hasil uji signifikansi dan linieritas persamaan regresi menunjukkan bahwa persamaan regresi sederhana $\hat{Y}=132,2924+2,0879 X_{I}$ signifikan dan berbentuk linier, artinya setiap peningkatan satu skor atau nilai $A Q$ akan diikuti oleh peningkatan skor atau nilai $O C B$ sebesar 132,2924 dengan konstanta 2,0879.

Persamaan regresi $\hat{Y}=132,2924+2,0879 X_{I}$ dapat digunakan untuk memprediksi skor $A Q$ apabila $O C B$ diketahui. Hasil uji signifikansi koefisien korelasi diperoleh $\mathrm{t}_{\text {hitung }}=6,21$ lebih besar dari $\mathrm{t}_{\text {tabel }}=1,98$ pada taraf signifikansi 0,05 dengan $\mathrm{dk}$ 155 menunjukkan bahwa koefisien korelasi antara $A Q$ dengan $O C B$ signifikan $\left(\mathrm{t}_{\text {hitung }}=6,21\right)>\left(\mathrm{t}_{\text {tabel }}=1,98\right)$. Dengan demikian, hipotesis nol $\left(\mathrm{H}_{0}\right)$ ditolak dan hipotesis alternatif $\left(\mathrm{H}_{1}\right)$ diterima, artinya terdapat hubungan positif yang signifikan antara $A Q$ dengan $O C B$. Kontribusi $A Q$ terhadap $O C B$ ditunjukkan oleh nilai koefisien determinasi $\left(\mathrm{r}_{\mathrm{y} 1}{ }^{2}\right)$ sebesar 0,1712 artinya $17,12 \%$ variabel $O C B(\mathrm{Y})$ dapat dijelaskan oleh variabel $A Q\left(\mathrm{X}_{1}\right)$ melalui persamaan regresi $\hat{Y}=132,2924+$ 
2,0879 $\mathrm{X}_{1}$. Hasil pengujian hipotesis pertama menunjukkan bahwa terdapat hubungan positif yang signifikan antara $A Q$ dengan $O C B$.

\section{Hubungan antara $S L$ dengan $O C B$.}

Berdasarkan hasil perhitungan, nilai koefisien korelasi $\left(\mathrm{r}_{\mathrm{y} 2}\right)$ sebesar 0,4137 termasuk pada kategori cukup kuat. Hal ini menunjukkan hubungan yang cukup kuat antara $S L$ dengan $O C B$. Hasil uji signifikansi koefisien korelasi diperoleh $t_{\text {hitung }}$ $=2,05$ lebih besar dari $\mathrm{t}_{\text {tabel }}=1,98$ pada taraf signifikansi 0,05 dengan $\mathrm{dk} 155$, menunjukkan bahwa koefisien korelasi antara $S L$ dengan $O C B$ signifikan $\left(\mathrm{t}_{\text {hitung }}=2,05\right)>\left(\mathrm{t}_{\text {tabel }}=1,98\right)$. Dengan demikian, hipotesis nol $\left(\mathrm{H}_{0}\right)$ ditolak dan hipotesis alternatif $\left(\mathrm{H}_{2}\right)$ diterima, artinya terdapat hubungan positif yang signifikan antara $S L$ dengan $O C B$.

Kontribusi $S L$ terhadap $O C B$ ditunjukkan oleh nilai koefisien determinasi $\left(\mathrm{r}_{\mathrm{y} 2}{ }^{2}\right)$ sebesar 0,0257 artinya $2,57 \%$ variabel $O C B(\mathrm{Y})$ dapat dijelaskan oleh variabel $S L\left(\mathrm{X}_{2}\right)$ melalui persamaan regresi $\hat{Y}=72,7648+0,7713 \mathrm{X}_{2}$. Hasil pengujian hipotesis kedua menunjukkan bahwa terdapat hubungan positif yang signifikan antara $S L$ dengan $O C B$.

\section{Hubungan antara $A Q$ dan $S L$ secara bersama-sama dengan $O C B$}

Hasil uji signifikansi koefisien korelasi ganda diperoleh $\mathrm{F}_{\text {hitung }}=24,09$ lebih besar dari $\mathrm{F}_{\text {tabel }}=3,05$ pada taraf signifikansi 0,05 dengan dk pembilang 2 dan dk penyebut 154 menunjukkan bahwa koefisien korelasi ganda antara $S L$ dengan $O C B$ signifikan $\left(\mathrm{F}_{\text {hitung }}=24,09\right)>\left(\mathrm{F}_{\text {tabel }}=3,05\right)$. Dengan demikian, hipotesis nol $\left(\mathrm{H}_{0}\right)$ ditolak dan hipotesis alternatif $\left(\mathrm{H}_{1}\right)$ diterima, artinya terdapat hubungan positif yang signifikan antara $A Q$ dan $S L$ secara bersama-sama dengan $O C B$. Kontribusi $A Q$ dan $S L$ terhadap $O C B$ ditunjukkan oleh nilai koefisien determinasi $\left(\mathrm{r}_{\mathrm{y} 12}{ }^{2}\right)$ sebesar 0,7218 artinya 72,18\% variabel $O C B(\mathrm{Y})$ dapat dijelaskan oleh variasi $A Q\left(\mathrm{X}_{1}\right)$ dan variasi $S L\left(\mathrm{X}_{2}\right)$ melalui persamaan regresi $\hat{Y}=12,2753+0,7536 X_{1}+0,3814 X_{2}$. Mencermati nilai dari masing-masing koefisien korelasi sederhana dan membandingkannya dengan nilai koefisien korelasi ganda terlihat bahwa terjadi efek saling menguatkan antara variabel $A Q\left(\mathrm{X}_{1}\right)$ dan $S L\left(\mathrm{X}_{2}\right)$. Hal ini terlihat dari nilai koefisien korelasi ganda antara $A Q$ dan $S L$ secara bersama-sama dengan $O C B\left(\mathrm{r}_{\mathrm{y} 12}=0,7218\right)$ yang lebih besar dari nilai koefisien korelasi sederhana antara $A Q$ dengan $O C B\left(\mathrm{r}_{\mathrm{y} 1}=0,4137\right)$ dan nilai koefisien korelasi sederhana antara $S L$ dengan $O C B\left(\mathrm{r}_{\mathrm{y} 2}=0,4137\right)$. Hasil pengujian hipotesis ketiga menunjukkan bahwa terdapat hubungan positif yang signifikan antara $A Q$ dan $S L$ secara bersama-sama dengan $O C B$.

\section{Korelasi Parsial}

Hasil analisis korelasi parsial antara $A Q\left(\mathrm{X}_{1}\right)$ dengan $O C B$ apabila variabel $S L$ dikontrol diperoleh nilai koefisien korelasi parsial $\left(\mathrm{r}_{\mathrm{y} 1.2}\right)$ sebesar 0,636 . Uji signifikansi koefisien korelasi parsial antara $A Q\left(\mathrm{X}_{1}\right)$ dengan $O C B$ dengan mengontrol variabel $S L$ dilakukan dengan uji t. Berdasarkan hasil uji signifikansi koefisien korelasi parsial, diperoleh $\mathrm{t}_{\text {hitung }}=$ 6,21 lebih dari $\mathrm{t}_{\text {tabel }}=1,98$ pada taraf signifikansi 0,05 dengan $\mathrm{dk} 154$ menunjukkan bahwa koefisien korelasi parsial antara $A Q\left(\mathrm{X}_{1}\right)$ dengan $O C B$ apabila variabel $S L$ dikontrol adalah signifikan $\left(\mathrm{t}_{\text {hitung }}=6,21\right)>\left(\mathrm{t}_{\text {tabel }}=1,98\right)$. dengan demikian, apabila variabel $S L$ dikontrol, tetap terdapat hubungan positif yang sangat signifikan antara $A Q\left(\mathrm{X}_{1}\right)$ dengan $O C B$. Berarti $S L$ tidak memengaruhi hubungan antara $A Q\left(\mathrm{X}_{1}\right)$ dengan $O C B$.

Hasil analisis korelasi parsial antara $S L\left(\mathrm{X}_{2}\right)$ dengan $O C B$ apabila variabel $A Q$ dikontrol diperoleh nilai koefisien korelasi parsial $\left(\mathrm{r}_{\mathrm{y} 2.1}\right)$ sebesar 0,069. Uji signifikansi koefisien korelasi parsial antara $S L\left(\mathrm{X}_{2}\right)$ dengan $O C B$ dengan mengontrol variabel $A Q$ dilakukan dengan uji t. Berdasarkan hasil uji signifikansi koefisien korelasi parsial, diperoleh $\mathrm{t}_{\text {hitung }}$ $=2,05$ lebih dari $\mathrm{t}_{\text {tabel }}=1,98$ pada taraf signifikansi 0,05 dengan dk 154 menunjukkan bahwa koefisien korelasi parsial antara $S L\left(\mathrm{X}_{2}\right)$ dengan $O C B$ apabila variabel $A Q$ dikontrol adalah signifikan $\left(\mathrm{t}_{\text {hitung }}=2,05\right)>\left(\mathrm{t}_{\text {tabel }}=1,98\right)$. Dengan demikian, apabila variabel Adverversity Quotient dikontrol, tetap terdapat hubungan positif yang sangat signifikan antara $S L\left(\mathrm{X}_{2}\right)$ dengan $O C B$. Berarti $A Q$ tidak memengaruhi hubungan antara $S L\left(\mathrm{X}_{2}\right)$ dengan $O C B$.

Tabel 1. Analisis Kontribusi Variabel-Variabel Penelitian

\begin{tabular}{|c|c|c|c|c|c|}
\hline No & Hubungan Antar Variabel & Koefisien Korelasi & Koefisien determinasi & Kontribusi & $\overline{\text { Urutan }}$ \\
\hline 1 & $\begin{array}{l}\text { Adversity Quetient dengan } \\
\text { Organizational Citizenship } \\
\text { Behavior }\end{array}$ & 0,636 & 0,1712 & $17,12 \%$ & 2 \\
\hline 2 & $\begin{array}{l}\text { Servant Leadership dengan } \\
\text { Organizational Citizenship } \\
\text { Behavior }\end{array}$ & 0,069 & 0,0257 & $2,57 \%$ & 3 \\
\hline 3 & $\begin{array}{l}\text { Adversity Quotient dan Servant } \\
\text { Leadership secara bersama- } \\
\text { sama dengan Organizational } \\
\text { Citizenship Behavior }\end{array}$ & 0,4137 & 0,7218 & $72,18 \%$ & 1 \\
\hline
\end{tabular}

Berdasarkan tabel di atas maka rumusan masalah dalam penelitian ini sudah terjawab, yaitu : (1) terdapat hubungan 
positif antara Adversity Quotient dengan Organizational Citizenship Behavior; (2) terdapat hubungan positif antara Servant Leadership dengan Organizational Citizenship Behavior; (3) terdapat hubungan positif antara Adversity Quotient dan Servant Leadership secara bersama-sama dengan Organizational Citizenship Behavior. Dalam penelitian korelasional dan analisis, metode SITOREM dipakai untuk: 1) mengidentifikasi kekuatan hubungan antara varibel bebas dengan variabel terikat, 2) menganalisis nilai indikator variabel penelitan yang berasal dari skor hasil penelitian , 3) menganalisis bobot masing-masing indikator dari tiap variabel penelitian dengan kriteria-kriteria yaitu: cost, benefit, urgency dan importance. Berdasarkan analisis model Scientific Identification Theory To Conduct Operation Research In Education Management (SITOREM) untuk melaksanakan "operation research" pada penelitian ini, diperoleh hasil perhitungan sebagai berikut.:

Tabel 2. Hasil Analisis SITOREM

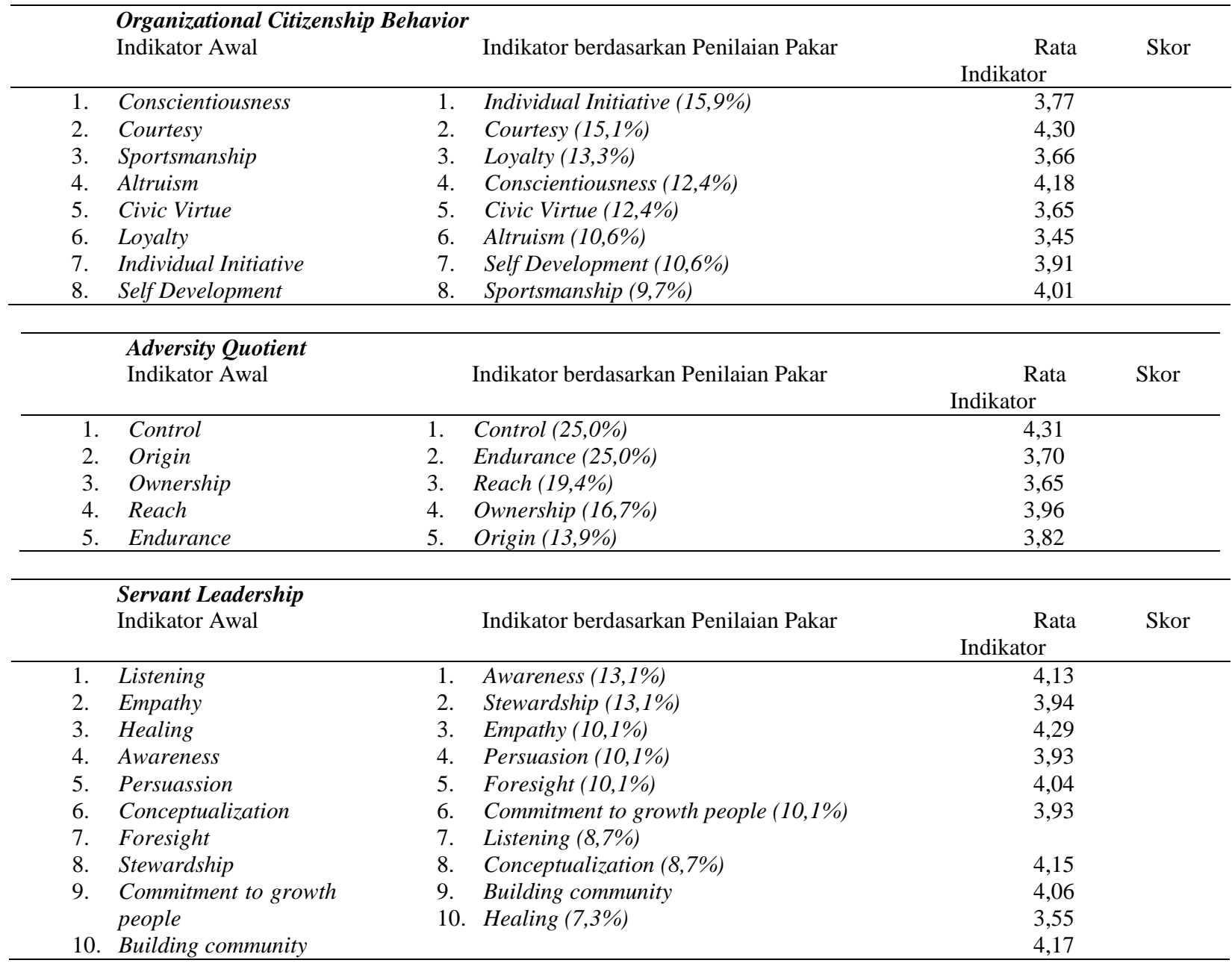

Tabel 3. Urutan Prioritas Indikator Diperbaiki dan Dipertahankan berdasarkan Hasil Analisis SITOREM

\begin{tabular}{|c|c|c|}
\hline & Urutan Prioritas Indikator Diperbaiki & Urutan Prioritas Indikator Dipertahankan \\
\hline 1. & Individual Initiative (15.9)(3.77) & Courtesy $(15.0 \%)(4.30)$ \\
\hline 2. & Loyalty $(13.3 \%)(3.66)$ & Conscientiousness $(12.4 \%)(4.18)$ \\
\hline 3. & Civic Virtue (12.4\%)(3.65) & 3. $\quad$ Sportsmanship $(9.7 \%)(4.01)$ \\
\hline 4. & Self Development (10.6\%)(3.91) & Control $(25.0 \%)(4.31)$ \\
\hline 5. & Altruism $(10.6 \%)(3.45)$ & 5. Awareness (13.0\%)(4.13) \\
\hline 6. & Endurance $(25.0 \%)(3.70)$ & 6. Empathy $(10.1 \%)(4.29)$ \\
\hline 7. & Reach $(19.4 \%)(3.65)$ & 7. Foresight $(10.1 \%)(4.04)$ \\
\hline 8. & Ownership $(16.7 \%)(3.96)$ & 8. Listening $(8.7 \%)(4.15)$ \\
\hline 9. & Origin $(13.9 \%)(3.82)$ & 9. Conceptualization $(8.7 \%)(4.06)$ \\
\hline 10. & Stewardship (13.0\%) (3.94) & 10. Healing $(7.2 \%)(4.17)$ \\
\hline \multicolumn{3}{|c|}{$\begin{array}{l}\text { 11. Commitment to growth people } \\
(10.1 \%)(3.93)\end{array}$} \\
\hline & Persuasion (10.1\%) (3.93) & \\
\hline & Building community (8.7\%)(3.55) & \\
\hline
\end{tabular}




\section{Pembahasan}

\section{Hubungan antara $A Q$ dengan $O C B$}

Hasil pengujian hipotesis pertama menunjukkan bahwa terdapat hubungan positif yang signifikan antara Adversity Quotient dengan Organizational Citizenship Behavior. Hasil penelitian ini sesuai dengan hasil penelitian Kusuma, Adriansyah dan Prastika (2013: 100-116) tentang pengaruh antara daya juang, kecerdasan emosional, dan modal sosial terhadap Organizational Citizenship Behavior karyawan dengan persepsi keadilan organisasi sebagai variabel moderasi. Hasilnya menunjukkan terdapat hubungan signifikan antara daya juang dengan Organizational Citizenship Behavior karyawan dengan beta 0.224, t = 2.510, dan $p=0.014<$ 0.050. Seirama dengan hasil penelitian ini dibuktikan oleh teori dari Ahmad dan As'ad (2007:101-105) yang menyatakan bahwa adversity intelligence dapat digunakan dengan mudah dalam organisasi. Adversity intelligence dalam organisasi dapat berperan dalam meramalkan siapa yang akan mampu mengatasi masalah-masalah yang timbul dalam aktivitas individu dalam organisasi. Semakin tinggi adversity intelligence dalam berorganisasi maka semakin tinggi pula kecenderungan individu untuk melampaui hambatan itu dengan sukses. Kesuksesan ini yang akan membuat individu merasa puas dan semakin termotivasi untuk melibatkan diri dalam aktivitas organisasi.

\section{Hubungan antara $S L$ dengan $O C B$}

Hasil pengujian hipotesis kedua menunjukkan bahwa terdapat hubungan positif yang signifikan antara Servant Leadership dengan Organizational Citizenship Behavior. Hasil penelitian ini sesuai dengan hasil penelitian Setiawan (2019:1-6) tentang pengaruh Servant Leadership terhadap Organization Citizenship Behavior melalui kepuasan kerja sebagai mediasi. Hasilnya menunjukkan bahwa Servant Leadership berpengaruh positif dan signifikan terhadap Organizational Citizenship Behavior melalui kepuasan kerja sebagai mediasi. Seirama dengan hasil penelitian ini dibuktikan oleh teori dari Pillai, Schrieshrim dan Williams (1999:897-933) yang menyatakan terdapat hubungan yang signifikan dan saling menguatkan antara tipe kepemimpinan, keadilan organisasi, komitmen kepuasan kerja, dan Organizational Citizenship Behavior (OCB). Pemimpin merupakan seseorang yang tindakan dan perilakunya menjadi contoh bagi pengikut. Keputusan yang ditentukan oleh pemimpin akan diikuti oleh karyawan. Selain cerdas dan bijaksana, pemimpin yang dibutuhkan adalah pemimpin yang mampu melayani karyawan. Hubungan pemimpin dengan karyawan yang dibangun dengan perilaku melayani akan menumbuhkan kedekatan emosional. Hal itu mendorong karyawan untuk meningkatkan kinerja Fahruna (2016:179-198).

\section{Hubungan antara $A Q$ dan $S L$ secara bersama-sama dengan $O C B$}

Hasil pengujian hipotesis ketiga sesuai dengan hasil penelitian Sukardewi, Dantes dan Natajaya (2013: 4) tentang hubungan Adversity Quotient terhadap kinerja guru SMA dapat disimpulkan bahwa terdapat kontribusi secara signifikan Adversity Quotient (AQ), terhadap Kinerja Guru SMA. Seirama dengan hasil penelitian ini dibuktikan oleh teori Supriyadi dalam Sukardewi, Dantes and Natajaya (2013) mengatakan bahwa untuk menjadi profesional, seorang guru dituntut memiliki lima hal yaitu : (1) guru memiliki komitmen yang tinggi pada siswa dan proses pembelajaran, (2) guru memiliki tanggung jawab terhadap pemantauan hasil belajar, (3) guru memiliki pengetahuan yang mendalam tentang materi yang diajarkan, (4) guru berpikir sistematis tentang apa yang diajarkan, dan selalu belajar dari pengalaman, dan (5) guru menjadi bagian dari masyarakat belajar di lingkungan profesinya. Penelitian serupa sebelumnya pernah dilakukan oleh Patras (2017) di lingkungan Perguruan Tinggi yang menunjukan bahwa terdapat pengaruh langsung positif perilaku kepemimpinan Kaprodi, keadilan organisasi, dan keterlibatan kerja terhadap $O C B$ anggotanya. Artinya untuk menumbuhkembangkan $O C B$ harus diiringi dengan perbaikan kepemimpinan, keadilan organisasi, dan meningkatkan keterlibatan kerja anggota organisasi.

\section{SIMPULAN}

Instrumen Organizational Citizenship Behavior, Adversity Quotient dan Servant Leadership yang memiliki validitas dan reliabilitas tinggi sangat dibutuhkan untuk penelitian yang bertujuan untuk meningkatkan Organizational Citizenship Behavior guru. Semua instrumen tersebut diperoleh dalam penelitian ini berasal dari tinjauan literatur, validasi ahli dan analisis data menggunakan skala Likert. Berdasarkan hasil pengujian menggunakan analisis SITOREM ditemukan 13 indikator variabel yang perlu diperbaiki dan 10 indikator variabel yang dapat dipertahankan dan dikembangkan. Pada penelitian ini juga dapat dibuktikan bahwa terdapat hubungan positif antara Adversity Quotient dan Servant Leadership dengan Organizational Citizenship Behavior baik secara bersama-sama ataupun sendiri-sendiri.

\section{REFERENSI}

Ajat. (2019). Pengaruh Kepribadian, Efikasi Diri dan Kepuasan Kerja terhadap Organizational Citizenship Behaviour Guru SMK Negeri di Wilayah 2 Jakarta Utara. Universitas Negeri Jakarta. 
Darto, M. (2014). Peran Organizational Citizenship Behavior (OCB) dalam Peningkatan Kinerja Individu di Sektor Publik : Sebuah Analisis Teoritis dan Empiris. Jurnal Borneo Administrator, 10(1), 10-34.

Fahruna, Y. (2016). Servant Leadership dan Kepuasan Kerja terhadap Kinerja Karyawan di Lembaga Keuangan Non Bank Pontianak. Jurnal Ekonomi Bisnis Dan Kewirausahaan, 5(3), 179-198.

Focht, A., \& Ponton, M. (2015). Identifying Primary Characteristics of Servant Leadership : Delphi Study. International Journal of Leadership Studies, 9(1).

García-cabrera, A. M., \& García-soto, M. G. (2011). MNC commitment , OCB role definition and intent to leave in subsidiary top managers : The moderating effect of uncertainty avoidance values. International Journal of Intercultural Relations, 35, 641-657. https://doi.org/10.1016/j.ijintrel.2011.02.008

Hema, G., \& Gupta, S. M. (2015). Adversity Quotient for Prospective Higher Education. The International Journal of Indian Psychology, 2(3).

Kusuma, A. R., Adriansyah, M. A., \& Prastika, N. D. (2013). Pengaruh Daya Juang, Kecerdasan Emosional, dan Modal Sosial terhadap Organizational Citizenship Behavior dengan Persepsi Keadilan Organisasi sebagai Variabel Moderasi. Jurnal Psikostudia Universitas Mulawarman, 2(2), 100-116.

Liden, R. C., Wayne, S. J., Zhao, H., \& Henderson, D. (2008). Servant Leadership : Development of A Multidimensional Measure and Multi-level Assesment. Elsevier, 19(2), 161-177.

Patras, Y. E. (2017). Pengaruh Perilaku Kepemimpinan, Keadilan Organisasi dan Keterlibatan Kerja terhadap Organizational Citizenship Behavior Dosen. Jurnal Ilmiah Pendidikan, 1(1), 8-14. Retrieved from http://journal.unpak.ac.id/index.php/pedagonal

Pillai, R., Schrieshrim, C. A., \& Williams, E. S. (1999). Fairness Perceptions and Trust as Mediators for Transformational and Transactional Leadership : A Two-Sample Study. Journal of Management, 25(6), 897-933.

Podsakoff, P. M., \& Mackenzie, S. B. (1994). Organizational Citizenship Behaviors and Sales Unit Effectiveness. Journal of Marketing Research, XXXI(August), 351-363.

Rachmawati, A. W., \& Lantu, D. C. (2014). Servant Leadership Theory Development \& Measurement. Procedia - Social and Behavioral Sciences, 115(Iicies 2013), 387-393. https://doi.org/10.1016/j.sbspro.2014.02.445

Saepudin, U., \& Djati, S. P. (2019). Pengaruh Kepuasan Kerja terhadap Organizational Citizenship Behavior (OCB) Guru dengan Komitmen Organisasional sebagai Variabel Mediasi. Jurnal Ilmiah Bisnis, Pasar Modal, Dan UMKM, 2(1), $123-136$.

Setiawan, W. S. (2019). Pengaruh Servant Leadership terhadap Organizational Citizenship Behaviour melalui Kepuasan Kerja sebagai Mediasi di PT. Cobra Dental Group. AGORA, 7(2), 1-6.

Suchyadi, Y. (2017). Relationship between Work Motivation and Organizational Culture in Enhancing Professional Attitudes of Pakuan University Lecturers. JHSS (Journal Of Humanities And Social Studies), 01(01), 41-45. https://doi.org/https://doi.org/10.33751/jhss.v1i1.372

Sukardewi, N., Dantes, N., \& Natajaya, N. (2013). Kontribusi Adversity Quotient (AQ), Etos Kerja, dan Budaya Organisasi terhadap Kinerja Guru SMA Negeri di Kota Amlapura, 4(2).

Tabrani, A. (2019). Pengaruh Budaya Sekolah dan Pemberdayaan terhadap Organizational Citizenship Behavior (OCB) Guru TK Yayasan Pelayanan Desa Terpadu di Indonesia Barat. Manajemen Pendidikan.

Tilova, N. (2019). Meninjau Kinerja Guru Islam : Adversity Quotient dan Spiritual Quotient. Scientific Journal of Reflecyion, 2(2), 211-220. https://doi.org/10.5281/zenodo.2628088

Verma, S., Aggarwal, A., \& Bansal, H. (2017). The Relationship between Emotional Intelligence ( EQ ) and Adversity Quotient ( AQ ). Journal of Business and Management, 19(1), 49-53. https://doi.org/10.9790/487X-1901024953

Wahyudi, D. (2019). Hubungan antara Servant Leadership dengan Organizational Citizenship Behavior (OCB) pada Karyawan. Universitas Islam Negeri Sunan Ampel.. 